\section{From Solidarity to Individualism in the Contemporary Couple}

\section{Iulian APOST' ${ }^{1}$}

${ }^{1} \mathrm{PhD}$, Scientific researcher, Institute of Sociology, Romanian Academy, Bucharest, Romania, phdiulian@gmail.com

\begin{abstract}
The contemporary society highlights a general type of marital behavior, still influenced by traditional sets of values. Today, the influence of the families of origin in the selection of the conjugal partner, in the marital decision and, often, in the way of organizing the functions of the family is obvious. Moreover, the general economic situation makes living with parents an alternative to consider. In this sense, the premises of modern marital relations are very difficult for some. At the same time, analyzing the national statistical data, we can see that the indicators that show the traditionality in the distribution of domestic roles show that over $50 \%$ of respondents consider that household chores should be done by women. Surprisingly, perhaps, if we compare the statistical data of the Gender Barometer from 2000 and 2018, we notice that, if in the first barometer, the share of those who believed in the female specifics of domestic roles was 63\%, in 2018, this opinion amounted to 53\% (Grumberg, Rusu, Samoilă, 2019). Beyond the general attitude, a new set of behaviors identified in young couples gradually legitimizes a new form of conjugal manifestation - relational individualism. The study aims to functionally evaluate these new tendencies of manifestation, analyzing the effects of relational individualism within the Romanian contemporary couple. The research bases its methodology on the utilitarian myth, that of the mutual fulfillment of needs, it is of a qualitative nature and the research instrument is the semi-structured interview.
\end{abstract}

Keywords: Individualism, solidarity, conjugal couple, autonomy, conjugal functionality.

How to cite: Apostu, I. (2020). From Solidarity to Individualism in the Contemporary Couple. Journal for Ethics in Social Studies, 4(1), 01-08. https://doi.org/10.18662/jess/4.1/23 


\section{Individualismul relational - funcţionalitate şi dileme contemporane}

Spațiul contemporan românesc surprinde un set de manifestări generale în ceea ce priveşte viaţa de cuplu care, încă mai face vizibilă înfluența tradițiilor asupra relațiilor conjugale. Astfel, bărbații se mai legitimează cu statusul masculin, mai mult decât să producă pentru el iar femeile încă mai tolerează inechitatea de rol în spațiul domestic. Cu toate acestea, o serie de comportamente noi fac vizibilă o altă logică a conjugalităţii - individualismul relational. Redusă ca pondere, comunitatea celor care mizează pe împlinirea personală prin celălalt, deschide premise spre individualitate însă, nu pentru a se recupera din conjugalitate ci pentru a-şi proteja mai bine identitatea, cu toate nevoile sale.

Alegerea partenerului în postmodernitate este scoasă aşadar din încastrarea socio-economică-morală anterioară, parteneriatul conjugal realizându-se în urma unei introspecții personale, de verificare a sinelui şi a emoțiilor interioare.

Pentru această categorie de cupluri, alegerea partenerului ține mai mult de logica sentimentelor decât de logica patrimoniului. Mai mult decat atât, opțiunile romantice sunt astfel psihologizate şi țin de individul cu dorințe proprii, $\mathrm{cu}$ interioritate şi sexualitate ca produs al unei societăți consumeriste, în care piața economică devine esențială. (Thierry, 2002, p.71) În complementaritate cu această idee, făcând referire la constituirea relațiilor conjugale în jurul unor emoții şi sentimente profund construite de ambii exponenți conjugali, se poate vorbi totodată şi despre existența mitului utilitarist care presupune că în relația de dragoste se manifestă, de fapt, schimbul social: îţi dau afecţiune, îmi dai afecţiune, îți ofer şi îmi oferi bunuri şi servicii, sunt părtaş la bucuria şi necazurile tale, iar tu faci la fel (Huidu, 2018). Astfel, multiplele şi variatele schimburi materiale, psihologice şi spirituale funcționează, într-adevăr în orice cuplu de îndrăgostiți însă nu neapărat într-un mod atât de mecanicist. (Iluţ, 2015, p.8)

Aşadar, indivizii devin din ce în ce mai izolați şi solitari în relațiile conjugale în aşa măsură încât căsătoria, care trebuie să constea într-o relație intimă, de interdependenţă între parteneri este considerată mai degrabă o modalitate de împlinire strict personală şi individualistă.(Santore, 2008, p.1203) Deoarece suntem purtători de abilităţi, de capacităţi şi de cunoştințe care trebuie să reziste în timp în stare activă, ne manifestăm dorinţa intrisecă de a ne păstra „, eu-l autentic” (,personal” si deci gândit ca „, A-social”), care nu şi-ar găsi locul în cadrul constrângător al societăţii. Această situație 
întăreşte iluzia existenței unui „eu intim”, autentic, independent de orice cadru social.( De Singly, 2000, p.1)

In acest sens, identitatea personală este un dat care vine de la sine şi care asteaptă validarea celor din jur. Deoarece raporturile sociale sunt inegale, unii îşi pot impune identificarea în timp ce ceilalți pot în permanență să tindă către identitatea acestuia, constatându-se un aspect naturalist şi conservator al acestei sociologii. Astfel, maniera în care sunt tratate raporturile sociale de gen, naturalizează şi psihologizează dispozițiile feminine, acestea din urmă având ,etică plină de afecțiune” pentru că ele nu cunosc o dezvoltare morală identică cu a bărbaților. (Ibidem, p. 185)

Aşadar, femeile şi bărbații experimentează dezvoltări noi, specifice modernității, bărbații ajungând să se întrebe despre ceea ce le mai este specific, triumful social al femeilor însemnând înfrângerea mentală a bărbaților, idee care s-a sedimentat în jurul accepțiunii că bărbații sunt mai vulnerabili şi mai fragili decât femeile. Mai mult decât atât, violențele susţinute, persistenţa inegalităţilor, a precarităţii crescute şi suferințele feminine fac obiectul unui proces de eufemism care ar trebui să ne incite să avem câteva bănuieli asupra funcției ideologice a masculinităţii. Punctând astfel vulnerabilitatea bărbaţilor, riscăm să garantăm ideea menținerii ordinii sociale cu care femeile sunt în aversitate. (Molinier, 2006) Această incongruență atât a feminității cât şi a masculinității se află într-o strânsă relație cu schimbările sociale actuale şi noua ordine socială stabilită de postmodernitatea aflată în conflict direct cu individul.

Conform lui Durkheim (1993), trăim într-o perioadă în care familia tradițională şi societatea modernă se află în declin, etica individului fiind în principal bazată pe împlinire personală, acesta dorind să fie autorul propriei sale vieți, creatorul identității individuale, societatea devenind în mod implicit din ce în ce mai fragmentată.

În ultima jumătate de secol, un număr mare de studii descriu viața socială ca fiind tot mai mult reconstituită în jurul actorilor sociali individualizați, care sunt în măsură să exercite autoritatea finală asupra propriei vieți. Dat fiind faptul că indivizii au devenit mult mai importanţi pentru societate şi că modele de personalitate individuală au fost revendicate atât de femei cât şi de bărbați, au apărut multe schimbări, inclusiv o transformare dramatică a sexualitătiii. Actul sexual a încetat să fie asociat dominant cu familia şi procrearea, ajungând să fie asociat prioritar cu individul şi plăcerea. (Frank, McEneaney, 1999, p.911)

Aceste schimbări la nivel global în ceea ce priveşte familia, locul de muncă sau oportunitățile sexuale pentru femei şi bărbaţi deschid perspectiva introducerii unei mai mari democrații, egalități şi libertăţi care nu obişnuiau 
să fie atât de impregnante în special pentru membrii minorităţilor sexuale. (Stacey, 1996, p.9)

Atracția sexuală capătă un loc central în opțiunea emoțională care ia amploare odată cu această schimbare a raporturilor în cuplurile conjugale contemporane. Astfel corpul şi nu caracterul devine cel esențial în opțiunea pentru un partener sau altul, transformare ce la rândul ei generează o serie de alte procese în care corpul este esențial pentru formarea unui parteneriat sufletesc, iar a fi sexy şi sex appeal-ul devin elemente centrale, angrenate în industria culturală din jurul emoției, a relaţiilor sufleteşti şi a iubirii.(Illouz, 2011, p.288) Această însemnătate atribuită sexualității este un determinant de valoare care remarcă forța incontestabilă a aspectului şi a narcisismului, prin definiție. Astfel, individul are nevoie de un fel de oglindă specifică şi anume ochii altora pentru a învăţa să se conformeze în el, întorcându-se la sine. De altfel, dacă individul nu se poate convinge de propria sa origine, el are nevoie de recunoaştere nu doar din asemănări, ci mai ales din ordinea simbolică pentru a-şi asigura o imagine identitară căuând motive de a fi şi de a-şi justifica existența. (Singly, 2000, p. 11).

Această tendință a relațiilor conjugale contemporane de a se concentra pe propria identitate şi de a evita controlul social în ordinea legăturilor de filiație, provine tocmai din dorinţa de a deține o anumită intimitate a vieții private, acest fenomen fiind cunoscut în literatura de specialitate drept individualismul negativ. Este vorba aşadar de viitorul legăturilor de filiație, individualismul pur hedonist tinzând spre emanciparea normelor constrângătoare fără ca altele noi, mai individualizate să le înlocuiască. În plus, acest individualism negativ triumfă dintr-o logică pur egoistă şi hedonistă pe care Irène Théry o numeşte „desimbolizare destructivă" ceea ce presupune reducerea raporturilor sexuate şi sexuale la o „ economie de plăceri” fără nicio referință la semnificaţia simbolică a relaţiei sexuale şi la dimensiunea identitară a relațiilor sexuale. (Théry apud Dubar, 2001, p 74)

Contrară acestei prezumții este teza „individualismului pozitiv” care refuză constatarea de dezinstituționalizare generalizată a familiei, statul intervenind din ce in ce mai mult dar nu doar prin legi, ci şi prin politici familiale care angajează concepții despre familie şi evoluțiile sale. Dragostea contemporană este din ce în ce mai mult considerată ca fiind ,negativul căsătoriei tradiționale”, ea nefiind tratată de dragostea care este „foarte complexă” şi poate „metafizică”, (Dubar, 2001, p. 81). Astfel, relația sexuală, prin plăcerea împărtăşită devine „revelatorul prin excelenţă al noii identităţi”, indivizii ajungând să îşi transpună manifestarea propriei identităţi sub incidența legăturilor sexuale, „fiecare simţindu-se promovat prin celălalt, în 
ce are el însuşi mai bun”. (Roussel 1989 apud Dubar, 2001, p 82). De cele mai multe ori, această transpoziție a propriului “eu” în „mrejele” celuilalt "eu" se soldează cu o manifestare a crizei amoroase pe care Roussel o numeşte „,captură captivă”. Aşadar, riscul de fuziune îl cuprinde pe cel de posesie şi de frustrare pentru că „dacă eu îmi capturez partenerul, îl împiedic să mă captiveze". Dacă unul îşi accentuează stăpânirea asupra celuilalt, celălalt fuge şi se sustrage: în numele victoriei sale, dominantul posesiv „,nu găseşte decât imaginea propriei sale dorințe”. Această identitate se adevereşte a fi ,iluzorie” datorită ,înţelegerii în taină” care provoacă „élusion” unuia şi „délusion” celuilalt. (Roussel, 1989)

\section{Individualismul relational - opinii sociale contemporane}

Există o diversitate de opinii şi raportări ale tinerilor la relaţia de cuplu, aceste diferențe izvorând tocmai din experiențe conjugale diferite. Cadrul general al opiniilor identificate în cercetare vizează devieri treptate de la logica solidarității. Prin actul socializării, tinerii primesc valorile clasice pe care ulterior şi le modifică datorită împrejurărilor concrete pe care le presupun experiențele conjugale. Astfel, eşecurile conjugale din relațiile conjugale anterioare devin premise unei alte abordări a viitoarelor relații, abordări care vizează de acum încolo logica îndeplinirii prioritare a nevoilor proprii.

Astfel, respondenții au ales să pună accentul pe stabilirea unui echilibru între nevoile fiecărui partener deoarece acestea ar trebui să fie importante în egală măsură, aşadar, există negocieri şi limite care stabilesc nevoile individuale ale partenerilor, graniţele şi tipul de interacțiune. Validarea relațiilor ține, aşadar, tocmai de feedback-ul intern al fiecărui partener în ceea ce priveşte îndeplinirea sistemului de nevoi.

Astfel, această dublă înplinire personală justifică acestora sentimentul de reciprocitate şi fuziune, fiecare dintre ei conservându-şi cât de mult poate din identitatea personală. Consecința acestei autonomii parteneriale constă în apariția unei vieți duble marcată de existența unei vieți conjugale asociată cu o viață personală. Putem considera că beneficiile vieții personale confirm şi validează viața conjugală. Această opinie de conservare a sinelui şi de prețuire a propriei persoane este promovată de majoritatea respondenților, existând însă şi opinii care se refereau în principal la găsirea unui echilibru între cele două aspecte ce sunt deosebit de marcante în funcţionarea unei relații. Aceast aspect poate fi explicat prin existenţa unor niveluri diferite de evoluție în parcursul conjugal de la modernitate la posmodernitate conjugală. În acest caz, nivelul de maturitate experiențială apare în relație de 
dependență cu opiniile conjugale care descriu tipul de solidaritate, ca sistem de elemente coezive orientate prioritar către parteneriat sau ca sistem intern de referință.

Analiza opiniilor sociale identificate în cercetare nu evidențiază decât ca excepție comportamente deplin adaptate teoriilor care descriu individualismul relational însă, noua logică de a înțelege şi contrui coeziunea internă a cuplului plasează pe un loc second interesul cuplului ca unitate în favoarea nevoilor individuale. Indeplinirea nevoilor devine, aşadar, motivația principală care justifică solidaritatea de grup.

Această schimbare a paradigmei de funcționalitate conjugală are meritul de a conserva şi mai bine autonomia individului, cuplul conjugal de succes fiind înțeles mai degrabă ca o sumă de două fericiri individuale decât ca unul care şi-a negociat scopuri şi nevoi comune.

Principiile individualismului relational apreciază relațiile conjugale etapizat. Validarea împlinirilor individuale crează solidaritatea conjugală iar fundamentarea solidarității deschide premise angajamentului relational de durată.

O altă justificare a preferințelor spre individualism relational care validează încă o data autonomia şi securitatea personală ține de controlul nivelului de implicare relaţională. Interviurile cu tinerii arătau relaţiile conjugale ca fiind de prioritate secundă, pe primul loc fiind dezvoltarea personală, studiile şi cariera. Principiile generale ale funcției de solidaritate conjugală presupun un nivel crescut de implicare, încă din primele faze de validare conjugală. Ele schimbă ordinea împlinirilor, principala fiind cea comună şi nu cea care protejează identitatea personală.

Această tendinţă de a evita asumarea responsabilităţii formării unui cuplu, îndeosebi la vârste destul de fragede în accepțiunea respondenților, reprezintă sursa necesităţii regăsirii de sine şi a identităţii personale a individului modern deoarece, conform teoriilor lui De Singly, suma calităților şi abilităților personale nu trebuie umbrite de orientarea generală a cuplului, prin acesta, fiecare individ având garantată conservarea "Eu-ului autentic". El nu se supune imperativelor sociale, nu este expresia cuplului ci a fiecăruia dintre cei doi parteneri.

Logica acestei noi forme de funcționalitate conjugală îşi poate asuma meritul de a explica sau anticipa şi creşterea vârstei pentru mariaj sau pentru fundamentarea unei relații, considerate a fi stabilă.

În acest sens se poate observa cum vârsta mai înaintată la care indivizii aleg să se implice în relaţii stabile dar şi dorinţa acestora de a-şi forma un statut, influențează asumarea unei vieți de cuplu care pare că este din ce în ce mai tergiversată de prioritățile personale. 
Un aspect interesant identificat în studiu a fost cel referitor la neimplicarea afectivă a partenerului. Dacă anterior, opiniile identificate vizau logica unei autonomii care justificau funcționalitatea noilor relaţii prin îndeplinirea nevoilor individuale, atunci când se face referire la celălalt, optica diferă - manifestarea sentimentelor de iubire, participarea afectivă sunt elemente de imputat celuilalt. Or, chiar şi această inconsistență valorică a unor aşteptări fără caracterul lor mutual arată şi justifică logica individualismului negative şi justifică egoismul şi hedonismul descris de Irène Théry în studiile sale.

Aşadar, se observă prezența unor situaţii de incongruenţă şi de risc conjugal asociat mentalităţilor individualiste în ceea ce priveşte manifestarea sentimentelor, confirmând riscurile de securitate emoțională.

\section{Concluzii}

Mecanică sau organică, solidaritatea conjugală a fost definite în sociologia familiei ca funcție de bază. În spațiul tradițional, solidaritatea mecanică nu era o solidaritate a individului sau a cuplului ci una socială, transmisă imperativ de comunitate ca set fix de reguli. Această personalitate colectivă a fost văzută de mentalitățile moderne ca fiind restrictivă. Pentru aceştia, solidaritatea organică avea să ofere tinerilor şansa de a-şi construi regulile de fuziune internă, contextele şi formele ei de manifestare. Şi acestea par apuse pentru unele cupluri contemporane deoarece varianta construcției comune presupune cedări de ambe părți. Logica individualismului relational presupune conservarea individualităţii iar solidaritatea nu mai este funcție ci consecința funcționalităţii, a împlinirii celor două fericiri individuale.

Această schimbare a societății postmoderne, atenționează De singly, îi transformă pe indivizi în subiecți autonomi, individuali, care trebuie să ia singuri decizii despre dorințele şi interesele lor, căsătoria fiind o arenă în care se reverberează această schimbare. Astăzi, alegerea formei de conviețuire conjugală nu mai necesită o legimitate externă, conformă cu normele sociale, instituționale sau a moralei comune ci se bazează mai degrabă pe forma unei recunoaşteri mutuale a celor doi parteneri, a sentimentelor şi respectului pe care şi-l poartă reciproc. Ideea de cuplu poate fi înțeleasă deci ca o reciprocă împlinire, însă în individualism, fiecare partener vrea să îşi conserve cât mai mult din identitatea personală deoarece nu doreşte să sufere din acceptarea constrângerilor celuilalt. Astfel, consecința acestei autonomii parteneriale constă în apariția unei vieți duble marcată de existența unei vieți conjugale asociată cu o viaţă personală. (De Singly, 2000, p.237) 
Premisele individualismului în cuplul contemporan mizează pe un update continuu în ceea ce priveşte funcționalitatea şi sistemul de nevoi personale. Acesta din urmă poate rămâne constant sau se poate schimba în funcție de noile experiențe iar dinamica interacțională a celor doi parteneri suportă continuu modificări şi revalidări relaţionale.

Analiza tezelor individualismului pozitiv deschid premise noi în cercetarea structurilor conjugale, cu atât mai mult cu cât, evoluția sistemului modern de funcționalitate arată că viața comună a doi parteneri care pornesc de la premisa solidarităţii derivă în multe cazuri în monotonie şi rutină iar strategia revigorării îşi trage seva din orientarea spre nevoile individuale. În acest sens, ne întrebăm retoric dacă individualismul relational este $\mathrm{o}$ experiență nouă în conjugalitate a unor cupluri tinere sau, pentru ceilalți, etapa a două, cea de dincolo de solidaritatea inițială!?

\section{Bibliografie}

De Singly, F. (2000). Le soi, le couple et la famille. Nathan/HER

Dubar, C. (2001). La crise des identités. Presses Universitaires de France

McEneaney, F. D. J. (1999). The Individualization of Society and the Liberalization of State Policies on Same- Sex Sexual Relations. Social Forces, 77(3), 911943. DOI: $10.1093 / \mathrm{sf} / 77.3 .911$

Grümberg, L. (coord.), Rusu, A., \& Samoilă, E. (2019). Barometrul de gen: România 2018. Editura Hecate.

Huidu, A. (2018). The ethics of embrionic stem cells research. The human being in the early stages of development: A "medicine" or an end in itself? În A. Sandu, A. Funză \& E. Unguru (Coords.), Ethics in research practice and innovation. Hershey, SUA: IGI Global. doi:10.4018/978-1-5225-63105.ch013

Illouz, E. (2012). Why love hurts: A Sciological Explanation. Polity Press

Iluț, P. (2015), Dragoste, familie şi fericire - Spre o sociologie a seninătății. Polirom

Molinier, P. (2006). L'enigme de la femme active. Égoïsme, sexe et compassion. Petite Biblioteque Payot

Roussel, L. (1989). La famille incertaine. Odile-Jacob.

Santore, D. (2008). Romantic Relationships, Individualism and the Possibility of Togetherness: Seeing Durkheim in Theories of Contemporary Intimacy. Sociology, 42(6), 1200-1217. https://doi.org/10.1177/0038038508096941

Stacey, R. D. (1996). Complexity and creativity in organizations. Berrett-Koehler Publishers

Thierry, B. (2002). L'individualisme dans la vie privée mythe ou réalité ? Projet, 2002/3 n 271, 71-80. DOI: 10.3917/pro.271.0071 